\title{
Enhancing Reading Comprehension of Iranian Advanced EFL Learners through Task-based Reading Activities
}

\author{
Vahid Fallah Golchin (Corresponding Author) \\ College of Foreign Languages and Literature, Science and Research Branch, IAU, Tehran, Iran \\ E-mail: vahid.fallah11@yahoo.com \\ Mostafa Dayyani Kheirabadi \\ Foreign Language Faculty, Tarbiat Modares University, Tehran, Iran \\ E-mail: dayyani.mostafa@yahoo.com
}

Received: 16-05-2013

doi:10.7575/aiac.ijalel.v.2n.5p.62
Accepted: 18-06-2013

Published: 01-09-2013

URL: http://dx.doi.org/10.7575/aiac.ijalel.v.2n.5p.62

\begin{abstract}
Language learning has experienced a shift of focus from a form-focused to a meaning-focused approach, and the necessity of using task-based learning, a relatively recent approach, has emerged. The vital role of task-based materials makes it obligatory not to exclude them from the language learning syllabi. The current study aims at investigating whether task-based reading can contribute significantly to the development of reading comprehension of Iranian advanced EFL learners of English. An experimental study was carried out in order to scrutinize the applicability of taskbased language teaching. To this end, 60 female advanced EFL learners, selected from among a pool of 100 learners, were assigned equally and randomly into two groups of thirty, consisting of an experimental and a control group. The selection of the participants was based on the results of a standard and piloted version of Paper-based TOEFL. The participant's mean age was about 23, ranging from 20 to 27 years of age. Both groups received a pretest and a post-test of reading. During the treatment period the experimental group received task-based reading activities while the control group received reading instructions through traditional methods. The impact of the treatment upon the reading comprehension ability of the participants was analyzed through an independent-samples t-test, and comparisons between groups were made. The results clearly indicated the development of reading comprehension ability of the participants in the first group (the experimental group) through the application of task-based reading activities.
\end{abstract}

Keywords: Task-based Reading, Traditional Reading, Reading Comprehension, EFL Learner

\section{Introduction}

The dearth of an appropriate cognitive theory of language learning and intensive target language use, two important drawbacks of the Communicative Language Teaching, paved the way for task-based language teaching, which is a substitute for CLT, to emerge (Klapper, 2003). According to Benevides and Valvona (2008) TBLT furnishes the basis for both instruction and assessment. They believe that using tasks as the stepping-stone of syllabus design allows teachers to both sequence lessons and assess their outcomes, while at the same time provides authentic parameters within which students will be able to communicate with each other for a purpose. Most importantly, it paves the way for focusing on what students are saying to one another, rather than on how they are saying it. They draw a distinction between short (e.g., ordering a sandwich by telephone) and long (e.g., organizing and publishing a book) tasks, but the tasks are always equipped with a clear and practical outcome.

For more effective language learning, according to Willis (2004), learners should actively process the meanings of the heard or read materials. To do this, designing different tasks can motivate learners to process the meaning and to accomplish a desired goal. Tilfarioglu and Basaran (2007) believe that in the traditional reading exercises, the emphasis was laid upon comprehension questions and structures which were uninteresting and monotonous to learners. However, in task-based learning students are provided with contextualized structures and forms to be used in appropriate contexts. In fact, there has been little direct research that would clarify what readers actually do while reading the texts (Richards, 1983, cited in O` Malley, Chamot, \& Kupper, 1989). Many conventional reading comprehension lessons pay little or no attention to improve the effectiveness of the learners' reading or to address their shortcoming as readers. In recent studies, one point, which is of paramount importance, is how to facilitate reading comprehension. Vandergrift (2003) believes that guiding learners to process reading can be advantageous from two practical perspectives. First, learners will be provided with essential knowledge to be more skilled readers. Second, readers will be motivated to take charge of their own learning.

Generally, each and every single teaching method has its own advocates who admire their own and criticize their opponents' views. Among these arguments the age-old problem about the usefulness of applying traditional reading instruction for better comprehension is still unanswered, and the appearance of new methods of teaching can call the feasibility of traditional reading exercises into question. Consequently, task-based language teaching can equip learners with essential knowledge and craft to overcome the barriers of language learning. 
2. Review of Literature

2.1 The Shift towards Communicative Language Teaching: A Brief Historical Overview

The inefficiency of the audiolingual method to teaching language in the1960's in preparing learners to communicate in the second language led to the emergence of CLT with a shift of focus on communication. Although spoken language was the primary goal of the audiolingual method, the approach adopted toward this objective was fundamentally flawed. Audiolingual method was premised on the assumption that learning a language is a process of habit formation and automatization i.e. learners could use language patterns accurately inside as well as outside the classroom, provided that 'presentation, imitation, and practice of patterns were included', shunning sinful errors (Willis, 2004).

Nonetheless, there were some problems inherent in the audiolingual method. Syllabuses represented a list of structural patterns demonstrated by contrived dialogues. It was transparent that learners were exposed to a limited version of the language, not to mention the fact that this manipulated language was quite dissimilar to the interactive spontaneity of speech learners would be exposed to in the outside world. In class, the teacher taught the coursebook and deprived learners of experimenting with language and expressing their own intended meanings. As a result, error-free and accurate production of the second language forms was emphasized over communication and negotiation of meaning (Willis, 2004). Chomsky (1959) fiercely criticizes the then-dominant views of language learning from a behaviorist perspective. He asserted clearly that language learning is a creative process and that it cannot be adequately and fully explained by theories of behaviorism. Chomsky proposes that language is 'rule-governed creativity' and is endowed with a basic rule system which is innate. He believes that children will internalize the basic rules of the language if they are simply exposed to a specific language. Therefore, learning in his view is considered to be a process of discovery affected significantly by internal processes overshadowing external influences (Willis, 2004). Widdowson (1978, cited in Willis, 2004), another critic of audiolingual method, states that a focus on language structure does not suffice to develop the capacity to express meanings.

CLT in its embryonic stage had a prime focus on practice of form rather than expression and negotiation of meanings by learners. It is still believed that teaching immediately results in acquisition and that the learned material (if it ever takes place successfully) will be an internalized and active part of the language learners' productive competence. However, as SLA research (Ellis, 2003) has shown teaching and learning are not linearly compatible and the learner's interlanguage cannot be easily traced to merely language instruction. In fact, learners do not practice as they are preached. Or to put it another way, learning what is taught and practiced cannot be guaranteed.

According to Tilfarioglou and Basaran (2007) CLT (communicative language teaching), a worldwide use method has, indeed, some noteworthy defects. Although it draws its principles from FLA (First Language Acquisition), it pays insufficient attention to the cognitive aspect of language learning and it lacks empirical research in the area of second language acquisition. Task-based learning is a potentially promising approach which can make up for the abovementioned drawbacks of the CLT.

\subsection{Task-based Language Teaching}

The emergence of communicative approach in the 1980's and its focus on communicative abilities of the learners led to a new approach, named task-based language teaching with the aim of designing process-oriented syllabuses and communicative tasks so as to develop the actual use of language. Within the different interpretations of TBLT connected to classroom practice, new studies shed light on its three inherent features: TBLT is in harmony with a learner-centered philosophy of education (Ellis, 2003); it is equipped with goal, procedure, and specific outcome (Skehan, 1998); it sides with content-oriented meaningful activities (Littlewood, 2004).

Considering the fact that language learning is highly affected by the intricate interactions of a network of factors including materials, activities, and evaluative feedback, TBLT can have a profound effect on these factors and variables. It is beyond question that TBLT provides meaningful material from authentic sources, perfect situations and contexts for interaction, and constructive feedback, thus maximizing the opportunities for language use. In EFL settings where learners are not exposed to the second language and do not interact meaningfully on a regular basis, it is of major importance to bring learners into contact with realistic language use in the classroom (Jeon \& Hahn, 2009).

There is a consensus among teachers that task-based instruction rests on three basic assumptions. These assumptions are:

1. Language learning/acquisition is a gradual and complicated organic process (Skehan, 1996, cited in Willis, 2004) which is not learned in a linear cumulative manner. In other words, teaching a discrete item will not result in the acquisition of that item.

2. "Language form is best learned when the learners' attention is on meaning" (Prabhu, 1982, cited in Willis, 2004, p.8). Therefore, language learning should be mainly meaning-focused rather than form-focused. The effort needed to wrestle to understand the meaning will simultaneously result in the subconscious acquisition of form. This calls for much-needed comprehensible input, that is, exposure to the target language in different contexts, both written and spoken, which is just slightly above the learners current level of understanding/comprehension (Krashen, 1985, 1988, cited in Willis, 2004; Ellis, 2003). This approach to foreign language learning is often called "Input Hypothesis".

3. Besides exposure to foreign language, SLA researchers (Swain, 1985; Ellis, 2003, cited in Willis, 2004) firmly believe that in order to learn a foreign language, learners must use the foreign language purposefully. To put it another way, interaction and output are also integral parts of learning.

Task-based learning is active learning and in such learning, the teacher shoulders the additional role of expert and knower plus allowing discussion and supportive help among learners. However, there should not be a structural hierarchy in task-centered learning. The role of the teacher in task-based learning is of major importance and he is a wise and experienced participant in the group work. The teacher can be considered as the learners' most privileged 
interlocutor, the teacher should motivate the participants to expend intensive mental energy in completion of the task. He should also support task performance in a way that integral processes such as the negotiation of content and meaning, the comprehension of rich input, the production of output, and focus on form which are believed to be fundamental in learning a language are triggered. (Cohen, Manion, \& Morrison, 1996)

Moor (1998) states that valuable task-based activities should have the following features:

"1.Intrinsic interest (personal anecdotes, discussing where there is a problem to be solved, etc)

2. The existence of an outcome or end product (records, videos, posters, etc)

3. Provision for language input (from the teacher, reference book)

4. Opportunities for silence, spontaneous speech, and prepared speech.”(p. 7)

Carless (2007) classifies the parameters for task type description into six categories. First, the learners are expected to speak, listen, read, and write in the real context. The next four categories deal with text genre, level of information processing, the role of a capable peer, and topic. The last one which is a complement to the first category is the degree of contextual support.

\subsection{Theoretical Framework of Task-based Learning}

Engaging learners in a variety of tasks is one of the challenges of task-based learning. Learners have many pedagogical needs that require a different approach to teaching. For instance, they need to be engaged in psycholinguistic and metalinguistic processes such as repeating, noticing forms, hypothesizing and conceptualizing rules (Nunan, 2004). For this reason, Nunan (2004) makes a distinction between two kinds of tasks: authentic or real-world tasks and pedagogical tasks. Real-world tasks are designed to emphasize those skills that learners are required to have in order to function in the real world. Such tasks share similarity with authentic task behavior, and their primary concern is to achieve an end product. Pedagogical tasks are designed to bridge the gap between the classroom and the real world to prepare learners for real-life language usage. They are designed to facilitate the language acquisition process by focusing on the teacher's pedagogical goal, the learner's developmental stage, and the social contexts of the second-language learning environment. They help learners in their understanding of how language works (Nunan, 2004).

\subsection{Definition of Task}

The confusing definition of a task in research and language pedagogy and its differentiation from an 'exercise' or an 'activity' are the reasons of finding task-based materials difficult to apply in language classroom contexts by some teachers. According to Crookes (1986), there is no unanimity as to what constitutes a task and there is no consistency regarding the description of the different devices for eliciting learner language.

There are two main definitions of tasks: the broad definition and the narrow definition. A broad definition according to Long (1985, cited in Ellis, 2003, p. 2), "includes tasks that require language", for instance making an airline reservation. And a narrow definition "defines task as an activity that necessarily involves language".

Nunan (1988):

A task is a piece of classroom work which involves learners in comprehending, manipulating, producing, or interacting in the target language while their attention is principally focused on meaning rather than form. The task should also have a sense of completeness, being able to stand alone as a communicative act in its own right. (p.10)

\subsection{Assessment of Task-based Performance}

There is a huge discrepancy between assessment of task-based performance and traditional formative tests in that assessment of task-based performance involves both the observation of performance in the real context and a simulation of a real-life task in a pedagogical context (Bachman, 2002).

According to Johnson and Johnson (1994), using authentic tasks for assessment does not necessarily mean recreating real-life activities, but it makes an effort to reflect learners' communicative abilities. When peer assessment is carefully designed, it is assumed to enhance the communication skills of learners with other members of the group by supporting and helping as well as challenging other team members to fulfill their potential.

\subsection{Task-Based Reading (TBR)}

The DART (Directed Activities Related to Text) model was proposed by Davies and Green (1984, cited in Nunan, 1999), and Davies (1995, cited in Nunan 1999) in reaction to traditional reading exercises which in their view are highly limited 'in their potential as learning activities'. Davies (1995, cited in Nunan, 1999) is in favor of tasks characterized by the following features:

"The good reading task:

- typically makes use of authentic and challenging texts;

- provides students with a rhetoric or topical framework for processing and analyzing the text;

- frequently involves an oral reading of the text by the teacher or a student followed by silent reading and rereading of the text;...

Through active reading tasks incorporating these features

- students make their hypotheses explicit;

- hypotheses are evaluated by other students and checked against the text;

- there is discussion about alternative interpretations;"... (Davies 1995, cited in Nunan, 1999, p.262).

These principles led to the development of the DART model. Within this model, two different task types predominate: reconstruction activities and analysis activities. Reconstructing a text is the primary focus of reconstruction activities. Transforming the information in the text is required from the reader in analysis activities (Nunan, 1999).

According to Nunan (1999) the following tasks are required to be completed in reconstruction activities (using text modified by teacher): 
- text completion

- $\quad$ sequencing

- $\quad$ prediction, ...

And the following tasks are attended to in analysis types of activities (using straight text):

- text marking

- labeling

- $\quad$ segmenting, ... (pp. 263-264)

Later some researchers such as Ellis (2003) and Willis (2004) have proposed the methodology of task-based teaching in practice and Hong-qin (2007) demonstrates the application of task-based teaching in reading classes.

Ellis (2003) and Hong-qin (2007) following Willis' (1998) framework for task-based learning propose that TBLT has three steps:

1. Pre-task stage (Pre-task)

2. Task-cycle (During task)

3. Language focus (Post-task)

\subsection{Reading Comprehension}

Reading comprehension is considered to be an internally complicated effort, employing the simultaneous use of conscious and unconscious strategies (such as problem-solving strategies) on the part of the reader, in order to infer a conceptual meaning from the writer's intended words (Dole, 2006).

Based on the above-mentioned points, the following null-hypothesis was stated:

H0: Task-based reading does not significantly improve the reading comprehension ability of Iranian advanced EFL learners.

\section{Method}

\subsection{Participants}

The participants were 60 female advanced EFL learners who were chosen from among a pool of 100 learners, randomly assigned into two groups of 30 learners, receiving ten sessions of instruction (treatment) of English reading class at Zabansara institute in Tehran. They were between 20 and 27 years of age, and shared the same language proficiency level. Based on the results of a TOEFL Test, the participants who answered 70 percent or more of the reading comprehension questions correctly, were considered advanced learners, and were used as the participants of the study. They were EFL learners of English and had been studying at the same Institute for about three years. The first 30 participants comprised the experimental group (task-based reading) and the next 30 participants comprised the control group (traditional reading).

\subsection{Instruments}

To meet the purposes of the present study, the following research instruments were used:

3.2.1 Proficiency Measures (Homogeneity Test)

A standard version of Paper-based TOEFL (PBT) was used. The test administered had 3 sections (structure, written expression, and reading comprehension):

Section 1: Structure (15 items)

Section 2: Written expression (25 items)

Section 3: Reading comprehension (50 items)

Its reliability was ensured through pilot-testing done with a group of 30 learners. The reliability index was 0.76 . The reading section of the homogeneity test (Paper-based TOEFL) was used before and after the treatment (as pre-test and post-test) to determine the participants' reading comprehension changes, if any.

\subsubsection{Instructional Materials}

The tasks that the experimental group received were selected from First Certificate Gold Practice Exams (Paran, 1996) and also IELTS reading tasks because they follow the principles and procedures of task-based language teaching.

Four types of tasks are always dominant in FCE reading exams. The first reading task usually consists of seven paragraphs. The students should choose the most suitable heading or summary for each paragraph from a list of eight headings or summaries. The second reading task requires the students to read a text and answer some multiple-choice items based on the text. The third reading task requires the students to read a text from which seven sentences or paragraphs have been removed. The students should complete the text by choosing a sentence or paragraph which fits each gap from a list of eight sentences or paragraphs. The fourth reading task comprises a few short independent texts, similar in topic, about which questions should be answered.

IELTS reading tasks include the following sections which are to be completed while reading a text (O'Connell, 2002):

- Matching tasks (sentence halves, opinions to sources, headings to paragraphs, causes and effects)

- Completion tasks (summary completion, sentence completion, note completion, diagram completion, flowchart completion, table completion, labeling a diagram, short-answer questions)

- True / False / Does Not Say and Yes / No / Not Given

- Classification tasks (similar to matching tasks)

- Multiple-choice questions

The instruction that the control group received was based on texts selected from Select Readings Upper-intermediate (Bernard and Lee, 2004). The texts were followed by different activities such as identifying the main idea, reference questions, fill-in-the-blank items, and analyzing the text organization. 


\subsection{Procedure}

Several procedures were carried out to accomplish the purposes of this research. First, the sampling was done and then the administered homogeneity test (Paper-based TOEFL) was used to assess the participants' language proficiency. The 60 homogeneous participants (selected from 100 participants) were divided randomly into two groups of 30 and both groups received the pre-test (reading section of the abovementioned Paper-based TOEFL Test).Then the treatment began. Task-based reading was the focus of one group (experimental group); traditional reading was the focus of the other group (control group).

Each session of the treatment period was broken down into three phases. In the first phase (pre-task stage) the participants were introduced to the topic of the reading texts; their prior knowledge was activated via questions and answers. In the second phase (during-task) the learners were required to read the instruction section of the task prior to approaching the text so as to know what to do. Then, a few minutes were allocated to silent reading, followed by initial answers to the questions which were monitored by the teacher. Learners were assigned to groups of two or three members to negotiate and discuss their answers with the help of the teacher's ongoing feedback. In the final stage (posttask) after task completion (on the part of the learners) the essential reading skills (e.g. skimming, scanning, inferencing, etc) were taught explicitly to the learners in order to enable the participants to complete the tasks collaboratively as well as individually.

The participants in the second group (traditional reading) did not receive any particular treatment because they comprised the control group. The linguistic features of the texts were highlighted through analyzing the structures, highlighting the vocabulary, discussing language points, and translating the text into their L1. The primary focus was on forms, and the negotiation of meaning did not play a major role in this approach to reading.

\section{Results and Discussion}

\subsection{Data Analysis and Results}

As mentioned before, the intended purpose of the present research was to see the possible contribution of task-based reading to reading comprehension development of Iranian advanced EFL learners of English.

In order to analyze and interpret the gathered data for testing the aforementioned null hypothesis, certain statistical procedures were utilized. This section pertains to the detailed discussion on the result of the analyses applied to the data. 4.1.1. Pretest of Reading Comprehension

After gathering the data, the SPSS (version 16) software was used for the data analysis. To achieve the purpose of the study, it was crucial to ensure that the data were normally distributed, i.e. they did not contradict the assumptions of normal distribution.

Descriptive statistics such as mean and standard deviation for the reading comprehension pretest of both groups can be seen in table 4.1 .

Table 4.1. Descriptive Statistics of Reading Comprehension Pretest by Groups

\begin{tabular}{|ll|r|r|r|c|}
\hline & & & & Std. Error \\
& groups & $\mathrm{N}$ & Mean & Std. Deviation & \begin{tabular}{c} 
Mean \\
\hline pretest
\end{tabular} Task-based Reading \\
& Traditional Reading & 30 & 23.0333 & 5.41698 & .98900 \\
& 30 & 22.1667 & 6.43312 & 1.17452 \\
\hline
\end{tabular}

Table 4.1 indicates that the mean scores of the reading comprehension pretest for both the experimental and the control groups are 23.03 and 22.16. It can also be seen that the standard deviation for task-based reading group is 5.41 and for the traditional reading group is 6.43 .

An independent t-test was used for the comparison of the mean scores of the experimental and the control groups on the pretest of reading comprehension prior to the administration of the task-based reading and traditional reading.

Table 4.2. Independent t-test for Pretest of Reading Comprehension by Groups

\begin{tabular}{|c|c|c|c|c|c|c|c|}
\hline & \multicolumn{2}{|c|}{$\begin{array}{c}\text { Levene's Test for } \\
\text { Equality of Variances }\end{array}$} & \multicolumn{4}{|c|}{ t-test for Equality of Means } \\
\hline & & $\mathrm{F}$ & Sig. & $\mathrm{t}$ & df & Sig. (2-tailed) & $\begin{array}{c}\text { Mean } \\
\text { Difference }\end{array}$ \\
\hline pretest & $\begin{array}{l}\text { Equal variances assume } \\
\text { Equal variances not } \\
\text { assumed }\end{array}$ & .752 & .389 & $\begin{array}{l}.564 \\
.564\end{array}$ & $\begin{array}{r}58 \\
56.366\end{array}$ & $\begin{array}{l}.575 \\
.575\end{array}$ & $\begin{array}{l}.86667 \\
.86667\end{array}$ \\
\hline
\end{tabular}

As displayed in table 4.2, the independent $\mathrm{t}$-test results $(\mathrm{t}=0.564)$ represent a weak effect size and indicate that the difference between the mean scores of both groups on the pretest of reading comprehension is non-significant. Thus one can conclude the homogeneity of the experimental and the control groups in terms of the reading comprehension ability before the administration of task-based reading and traditional reading.

It is noteworthy that the homogeneity assumption of variances is met. As can be seen in the first row of table 4.2, the Levene's F-value is not significant $(\mathrm{F}=0.75)$. That is why "Equal variances assumed" is reported. 


\subsubsection{Posttest of Reading Comprehension}

Table 4.3 shows descriptive statistics for the reading comprehension post-test by groups.

Table 4.3. Descriptive Statistics of Reading Comprehension Post-test by Groups

\begin{tabular}{|ll|r|r|r|r|}
\hline & & & & & Std. Error \\
& groups & $\mathrm{N}$ & Mean & Std. Deviation & Mean \\
\hline posttest & Task-based Reading & 30 & 27.2000 & 5.36528 & .97956 \\
& Traditional Reading & 30 & 23.0000 & 7.76375 & 1.41746 \\
\hline
\end{tabular}

Based on table 4.3, the mean scores for the post-test of reading comprehension are 27.20 for the experimental group and 23 for the control group; the standard deviations for both groups are 5.36 and 7.76 respectively.

An independent t-test was used to compare the mean scores of the experimental and control groups on the posttest of reading comprehension after the administration of the task-based reading and traditional reading.

Table 4.4. Independent t-test for Posttest of Reading Comprehension by Groups

\begin{tabular}{|c|c|c|c|c|c|c|c|}
\hline & & \multicolumn{2}{|c|}{$\begin{array}{c}\text { Levene's Test for } \\
\text { Equality of Variances }\end{array}$} & \multicolumn{4}{|c|}{ t-test for Equality of Means } \\
\hline & & $\mathrm{F}$ & Sig. & $\mathrm{t}$ & $d f$ & Sig. (2-tailed) & $\begin{array}{c}\text { Mean } \\
\text { Difference }\end{array}$ \\
\hline posttest & $\begin{array}{l}\text { Equal variances assumed } \\
\text { Equal variances not } \\
\text { assumed }\end{array}$ & 1.930 & .170 & $\begin{array}{l}2.438 \\
2.438\end{array}$ & $\begin{array}{r}58 \\
51.555\end{array}$ & $\begin{array}{l}.018 \\
.018\end{array}$ & $\begin{array}{l}4.20000 \\
4.20000\end{array}$ \\
\hline
\end{tabular}

The results of table 4.4 represent a strong effect size $(\mathrm{t}=2.438)$ and show that the difference between the mean scores of both groups on the reading comprehension post-test is significant. The conclusion is that the null hypothesis as taskbased reading does not improve significantly the reading comprehension ability of Iranian advanced EFL learners is rejected. The subjects in the experimental group, after receiving task-based reading activities, significantly improved their reading comprehension ability.

It needs mentioning that the homogeneity assumption of variances is met. As can be seen in the first row of table 4.4, the Levene's F-value is not significant $(\mathrm{F}=1.930)$. That is why "Equal variances assumed" is reported.

\subsection{Discussion}

As the analyses showed, participants in the first group (task-based reading) made significant progress in their posttest with respect to reading comprehension. Therefore, the treatment had a positive effect on the performance of this group.

Task-based reading significantly improved the reading comprehension ability of the participants. "Task-based teaching can be viewed as a new orthodox within contemporary ELT (Littlewood, 2004), falls within the general umbrella of communicative language teaching (CLT) and can be seen as an offshoot from it (Kumaravadivelu, 2006)" (cited in Carless, 2007, p. 595). An overwhelming majority of research and literature written has been on the theoretical aspects and issues of task-based instruction. That is, task-based language teaching has come to be accepted theoretically as a new paradigm and method in the second and foreign language learning research. However, experimental research on the issue of TBLT is poor (Sanchez, 2004; Carless, 2007).

Sheen (1994, p. 127) in his analysis of task-based language teaching, in the last decade of the twentieth century when task-based approach had gained popularity in the field of language teaching (Sanchez, 2004), calls attention to his critical observation that the change of focus in the field of language learning (from form to meaning) does not guarantee an eye-catching progress in the realm of language learning. This controversial claim, based on realistic observation and analysis of task-based syllabus, does not support the findings of the present study regarding task-based reading which yielded significant progress in the development of the students' reading comprehension. Sheen (1994, p. 127) argues that "the fault seems to lie in the overstatement of criticisms directed at existing paradigms and the failure to challenge the validity of the advantages imputed to replacements". He suggests that such new proposals, for instance task-based syllabus, must be submitted to critical scrutiny. Sheen (1994, p. 127) concludes that "the priority for advocates of taskbased syllabus should lie in the necessity to demonstrate the greater effectiveness of such an approach over those of a more conventional nature". Sanchez (2004, p. 65) goes even further and argues that recent methods should not considered as "innately good and efficient by their nature, or simply because they are new".

The fact that task-based reading produced significant results in students' scores regarding the development of reading comprehension in this study confirms researchers' preoccupation with meaning (Ellis, 2003). Therefore, the effectiveness of task-based instruction regarding reading comprehension can be justified because "task-based approaches emphasize communication of meaning rather than study of grammatical form as the starting point for learning activities" (Carless, 2007, p. 596).

In the literature on task-based instruction, there are contradictory assumptions and theories on the issue reading comprehension. Klapper (2003, cited in Carless, 2007, p. 597) believes that task-based language teaching regards language acquisition "as being too close to L1 processes to be applicable in EFL contexts". The history between taskbased materials and learning improvement has always been a matter of controversy for teachers and this issue has raised doubts over the usefulness of task-based instruction (Loumpourdi, 2005, cited in Carless, 2007). 
In TBLT grammatical form and grammar instruction are normally pointed out in the post-task stage known as "focus on form' (Ellis, 2003, Carless, 2007). This stage furnishes the basis for explicit learning. In task-based reading where the main focus and attention is channeled into the completion of the tasks; students are not left with boredom and lethargy. On the plus side, grammar instruction might receive equal and adequate attention.

In the end, it should be remembered that "what we urgently need is to do more research on the mechanisms of learning and accompany new proposals and methods with more experimental evidence before we bring them into the classroom" (Sanchez, 2004, p. 65).

\section{Conclusion}

Task-based language teaching encourages the shift from teacher dependence toward learner independence and lays the foundation for the active participation on the part of the learners through task performance. Although it is generally accepted that reading tasks play a major role in the language learning process, the research in this regard is still poor.

This study was an attempt to investigate the contribution of task-based reading activities to the development of reading comprehension ability of Iranian advanced EFL learners. In the mean time, the mean scores of the first group participants (task-based reading), before and after treatment (pretest and post-test), were compared with the means of scores gained by the participants in the second group (traditional reading) which functioned as the control group. The results of the study confirm the effectiveness of applying task-based reading activities on the development of reading comprehension.

Practical situations which are used in traditional approaches toward language learning might no longer be interesting for upper-intermediate through advanced learners. Therefore, traditional reading can create controversial topics for reading and discussing for advanced learners.

The findings of this research would be of great interest for language teachers who are interested in improving the reading comprehension ability of EFL learners by using task-based activities. Task-based reading is a manifestation of language in use and is a communicative tool for language learning.

\section{References}

Bachman, L. (2002). Some reflections on task-based language performance assessment. Language Testing19, 453-476. http://dx.doi.org/10.1191/02655322021t240oa

Benevides, M., \&Valvona, C. (2008). Task-based language teaching. [Online] Available: http://www.widgetsinc.com/downloads/download.php?file Name...tblt.pdf (April 15, 2012)

Bernard, J. \& Lee, L. (2004). Select readings: Upper-intermediate. Oxford: Oxford University Press.

Carless, D. (2007). The suitability of task-based approaches for secondary schools: Perspectives from Hong Kong. System, 35, 595-608. http://dx.doi.org/10.1016/j.system.2007.09.003

Chomsky, N. (1959). Review of skinner's verbal behavior. Language, 35, 26-58. http://dx.doi.org/10.2307/411334

Cohen, L., Manion, L. \& Morrison, K. (1996). A guide to teaching practice. London: Routledge.

Crookes, G. (1986). Towards a validated analysis of scientific text structure. Applied Linguistics, 7, 57-70. http://dx.doi.org/10.1093/applin/7.1.57

Dole, J. A. (2006). Help with teaching reading comprehension: Comprehension instructional frameworks. International Reading Association, 59(8), 742-753.

Ellis, R. (2003). Task-based language learning and teaching. Oxford: Oxford University Press.

Jeon, I. J., \& Hahn, J. W. (2009). Exploring EFL teachers' perceptions of task-based language teaching: A case study of Korean secondary school classroom practice. Asian EFL Journal, 8(1), 10-32.

Johnson, D., \& Johnson, R. (1994). Learning together and alone: Cooperative, competitive and individualistic learning. Massachusetts: Allyn and Bacon.

Hatch, E. \& Lazaraton, A. (1995). The research manual: Design and statistics for applied linguistics. Boston: Heinle $\&$ Heinle Publishers.

Hong-qin, Y. (2007). Application of TBT in reading class. US-China Education Review, 4(5), 39-42.

Klapper, J. (2003). Taking communication to task? A critical review of recent trends in language teaching. Language Teaching Journal, 27(1), 33-42.

Littlewood, W. (2004). Task-based approach: Some questions and suggestions. ELT Journal, 58(4), 319-326.

Mahdavy, B. (2008). The role of multiple intelligences in listening proficiency: A comparison of TOEFL and IELTS listening tests from an MI perspective. [Online] Available: http://www.asian-efl-journal.com/September_08_bm.php (May 12, 2012)

Moor, P. (1998). Task-based approach to oral work. [Online] Available: http://www.ihworld.com/ihjournal/a_task_based_approach_to_oral_work_by_pete_moor.doc (March 25, 2011)

Nunan, D. (1988). Syllabus design. Oxford: Oxford University Press.

Nunan, D. (1999). Second language teaching and learning. Boston: Heinle and Heinle

Nunan, D. (2004). Task-based language teaching. Cambridge: Cambridge University Press.

O'Connell, S. (2002). Focus on IELTS. Pearson Education Limited: England.

O'Malley, J. M., Chamot, A. U., \& Kupper, L. (1989). Listening comprehension strategies in second language acquisition. Applied Linguistics, 10 (4), 418-437.

Paran, A. (1996). First certificate gold practice exams. Addison Wesley Longman Limited: England.

Pierce, B. N. (1992). Demystifying the TOEFL Reading Test. TESOL Quarterly, 26 (4), 665-692. http://dx.doi.org/10.2307/3586868 
Raimes, A. (1990). The TOEFL test of written English: Causes for concern. TESOL Quarterly, 24(3) 427442. http://dx.doi.org/10.2307/3587228

Sanchez, A. (2004). The task-based approach in language teaching. IJES. International Journal of Language Studies, $4(1), 39-71$.

Sheen, R. (1994). A critical analysis of the advocacy of the task-based syllabus. TESOL Quarterly, 28, 127-157. http://dx.doi.org/10.2307/3587202

Skehan, P. (1998). A cognitive approach to language learning. Oxford: Oxford University Press.

Tilfarioglu, F., \& Basaran, S. (2007). Enhancing reading comprehension through task-based writing activities. The Reading Matrix, 7(3), 134-172.

Vandergrift, L. (2003). From prediction through reflection: Guiding students through the process of L2 listening. The Canadian Modern Language Review, 59(3), 463-496.

Willis, J. R. (2004). An overview of task-based instruction: From theories to practices. NW Washington: Georgetown University Press. 